\title{
IMPLEMENTASI STRATEGI PEMASARAN PADA KOPERASI KARYAWAN PT. BRIDGESTONE TIRE INDONESIA
}

\author{
Deni Heryadi ${ }^{1}$, Endah Widati ${ }^{2}$ \\ ${ }^{1,2}$ Program Studi Pendidikan Ekonomi, FIPPS \\ Universitas Indraprasta PGRI \\ e-mail: ${ }^{1)}$ dehta1205@yahoo.com; ${ }^{2)}$ endahwidati82@gmail.com
}

\begin{abstract}
According to Ministry of Cooperatives and SMEs, there are 212,315 cooperatives listed and only 71\% is active. Most of the active cooperatives are employee cooperatives. The data shows that recently 14.252 active employees cooperation with total members up to 1.586 .811 people. PT. Bridgestone Tire Indonesia Employee Cooperative (BSIN employee Cooperative) is one of employee cooperative that have a huge income. This research aims to find out the key success factor of management and marketing strategic implementation which applied by BSIN employee cooperatives. Methods used in this research are combination methodologies research both qualitative and quantitative. Researchers also used few methods to analyzing such as descriptive analysis, VRIO framework analysis and marketing matrix. The result can be used as recommendation for BSIN Cooperative and others cooperatives as a benchmarking basis, so the performance can be better.
\end{abstract}

\begin{abstract}
ABSTRAK
Berdasarkan data Kementerian Koperasi dan UMKM, per tahun 2015 tercatat sebanyak 212.315 Koperasi dan yang aktif hanya 150.223 koperasi atau $71 \%$ dari koperasi yang terdaftar. Dari data tersebut jumlah koperasi aktif di Indonesia, sebagian besar adalah koperasi karyawan (KopKar). Koperasi karyawan saat ini berjumlah 14.252, dengan jumlah anggota sebanyak 1.586.611, dan sebarannya merata di seluruh Indonesia. Koperasi Karyawan PT Bridgestone Tire Indonesia (Kopkar BSIN) merupakan salah satu koperasi karyawan besar yang memiliki omzet sangat tinggi. Penelitian ini dilakukan bertujuan untuk mengetahui kunci kesuksesan pengelolaan dan penerapan strategi yang dijalankan sehingga dapat membuat Kopkar BSIN menjadi kopkar dengan omzet yang sangat tinggi. Dalam penelitian ini, tim menggunakan metode penelitian kombinasi antara kualitatif dan kuantitaf, dengan menggunakan beberapa teknik analisis data seperti: analisis deskriptif, analisis VRIO dan matrik pemasaran. Adapun hasil penelitian ini dapat dijadikan rekomendasi bagi kopkar PT Bridgestone Tire Indonesia dan kopkar perusahaan yang lain sebagai benchmarking untuk menjadi kopkar yang lebih baik lagi.
\end{abstract}

Kata Kunci: Strategi Pemasaran, Koperasi Karyawan, Matrik Pemasaran 


\section{PENDAHULUAN}

Perkembangan kopkar yang signifikan menunjukkan bahwa banyak perusahaan sangat memperhatikan perkembangan kopkar yang dimiliki. Berdasarkan data diketahui bahwa dari jumlah 14.252, Kopkar mampu mencatat volume usaha mencapai Rp 25.361 triliun, dengan sisa hasil usaha (SHU) Rp 11.692 triliun. Hal ini dimungkinkan karena perusahaan memiliki kapabilitas pengelolaan yang baik, namun memang tidak sedikit pula perusahaan yang mendirikan koperasi karyawan dikarenakan adanya keharusan untuk ada koperasi disetiap perusahaan. Oleh karenanya penting bagi perusahaan untuk dapat memahami bahwa mendirikan koperasi karywan dan mengelolanya memiliki banyak manfaat seperti karyawan akan sibuk dengan kegiatan produktif, terjalin komunikasi yang baik antar karyawan, tersedianya sumber pendanaan untuk memenuhi kebutuhan mendadak atau bersifat urgen dan jangka panjang serta memberikan kesempatan karyawn untuk dapat menambah pengetahuan dan mengembangkan diri tentang berwirausaha. Koperasi Karyawan PT Bridgestone Tire Indonesia merupakan salah satu koperasi karyawan besar yang memiliki omzet sangat tinggi. Adapun kategori level untuk koperasi karyawan PT Bridgestone Tire Indonesia adalah level A dimana level ini menunjukkan pengelolaan dan pendapatan yang sangat signifikann. Oleh karenanya tim pengusul ingin melakukan penelitian yang berkaitan dengan implementasi strategi pemasaran pada PT Bridgestone Tire Indonesia sehingga dapat diketahui kunci kesuksesan pengelolaan dan penerapan strategi yang telah dijalankan. Selain itu, tim peneliti juga ingin mengetahui hasil dari implementasi strategi pemasaran yang telah dijalankan selama periode 2011 - 2015 .

Kotler dan Keller (2016:74) mengemukakan bahwa "strategy is a company's game plan for achieving its goals". Strategi merupakan cara bagaimana organisasi atau individual mencapai tujuannya (Grant, 2008:17). Setiap organisasi baik profit organization maupun non-profit organization memerlukan strategi untuk mencapai tujuannya.

Untuk mencapai tujuan pemasaran, pemasar memerlukan strategi pemasaran. Strategi pemasaran merupakan rencana yang menjabarkan ekspektasi perusahaan akan dampak dari berbagai aktivitas atau program pemasaran terhadap permintaan produk atau lini produknya di pasar sasaran tertentu (Tjiptono dan Chandra, 2012:193). Sedangkan strategi pemasara menurut Cravens dan Piercy (2013:15) adalah "a marketdriven process of strategy development, taking into account a constantly changing business environment and the need to deliver superior customer value "

Sehingga dapat disimpulkan bahwa strategi pemasaran adalah rencana strategik dan taktikal yang digunakan oleh pemasar untuk mencapai tujuan pemasaran dengan mempertimbangkan perubahan lingkungan, luas dan mikro, serta nilai konsumen yang superior (unggul) yang diinginkan oleh konsumen.

Crevens dan Piercy (2013) menjelaskan bahwa ada 4 langkah proses strategi pemasaran yang harus dilakukan dalam merencanakan dan mengembangkan strategi pemasaran, yaitu: menentukan segmentasi dan nilai konsumen, merancang strategi berorientasi pasar, mengembangkan program berorientasi pasar, mengimplementasikan dan mengelola strategi berorientasi pasar. Sebuah rencana hanya akan menjadi rencana tanpa sebuah aksi realisasi. Sehingga untuk mengetahui apakah rencana dan program yang dirancang akan memberikan hasil atau tidak maka rencana tersebut harus diimplementasikan dan dikelola dengan baik.

Selain itu, organisasi perlu menyadari bahwa dalam proses perencanaan strategi pemasaran ada 3 (tiga) dimensi yang harus diperhatikan (Crevens dan Piercy, 2013) yaitu: dimensi proses analisis yang terdiri dari teknik model, prosedur dan sistem perencanaaan; dimensi proses prilaku yang didalamnya termasuk persepsi manajerial, asumsi dan persepsi strategik, dan dimensi terakhir adalah dimensi proses organisasi yang terdiri dari struktur, budaya dan informasi.

Setelah membuat rencana pemasaran maka orgasasi harus mengimplementasikan rencana tersebut sehingga hasil dari strategi yang dibuat dapat diketahui. Untuk mengimplementasikan strategi pemasaran organisasi harus memutuskan siapa (who) yang akan bertanggung jawab, kapan (when) akan di eksekusi, bagaimana (how) strategi tersebut akan dilaksanakan serta program 
apa (what) yang akan dilaksanakan. (Crevens dan Piercy, 2013). Selanjutnya adalah evaluasi dan pengendalian. Evaluasi dan pengendalian dilakukan dengan tujuan untuk menemukan kesempatan baru dan menghindari ancaman, menjagaa kinerjaagar sesuai harapan manajemen serta menyelesaikan masalah yang spesifik timbul.

\section{METODE}

Dalam penelitian ini, tim menggunakan metode penelitian kombinasi antara kualitatif dan kuantitaf (Sugiono, 2012), dengan menggunakan beberapa teknik analisis data seperti: analisis deskriptif (Sugiono, 2012), analisis VRIO (Barney, 1991) dan matrik pemasaran (Crevens dan Piercy, 2013; Tjiptono dan Chandra, 2012) yakni matrik profitabilitas (Tjiptono dan Chandra, 2012), matrik proses internal (Hammer, 2007) dan matrik inovasi (Kyffin dan Gardien, 2009)

\section{HASIL DAN PEMBAHASAN}

Berdasarkan tabel 1 hasil penelitian analisis VRIO menunjukkan bahwa rata-rata kemampuan yang dimiliki oleh Kopkar BSIN menunjukkan kemampuan yang mengarah pada keunggulan kompetitif sementara yang berarti bahwa setiap kemampuan memiliki peluang menjadikan kopkar BSIN menjadi kopkar yang dapat menghasilkan dan memdapatkan hasil diatas normal atau diatas rata-rata.

\section{Analisis VRIO}

Tabel 1. Hasil Analisis VRIO

\begin{tabular}{|c|c|c|c|c|c|}
\hline Sumber Daya / Kemampuan & Valuable & Rarity & $\begin{array}{l}\text { Costly } \\
\text { to } \\
\text { imitate }\end{array}$ & Organize & Hasil kemampuan \\
\hline Keuangan & Ya & Tidak & Tidak & Ya & $\begin{array}{c}\text { Paritas Kompetitif } \\
\text { Keunggulan }\end{array}$ \\
\hline Aset tetap & Ya & Ya & Tidak & Ya & $\begin{array}{l}\text { Kompetitif } \\
\text { Sementara }\end{array}$ \\
\hline Sumber Daya Manusia & Ya & Tidak & Tidak & Ya & $\begin{array}{c}\text { Paritas Kompetitif } \\
\text { Keunggulan }\end{array}$ \\
\hline Kemampuan Organisasi & Ya & Tidak & Ya & Ya & $\begin{array}{c}\text { Kompetitif } \\
\text { Sementara } \\
\text { Keunggulan }\end{array}$ \\
\hline Kemampuan Pembelajaran & Ya & Tidak & Ya & Ya & $\begin{array}{c}\text { Kompetitif } \\
\text { Sementara } \\
\text { Keunggulan }\end{array}$ \\
\hline Loyalitas Anggota & Ya & Tidak & Ya & Ya & $\begin{array}{l}\text { Kompetitif } \\
\text { Sementara }\end{array}$ \\
\hline Kontrak dan Hubungan & Ya & Tidak & Tidak & Ya & $\begin{array}{c}\text { Paritas Kompetitif } \\
\text { Keunggulan }\end{array}$ \\
\hline Jaringan Luar & Ya & Ya & Tidak & Ya & $\begin{array}{l}\text { Kompetitif } \\
\text { Sementara }\end{array}$ \\
\hline Lokasi Geografis & Ya & Tidak & Tidak & Ya & $\begin{array}{c}\text { Paritas Kompetitif } \\
\text { Keunggulan }\end{array}$ \\
\hline Berinovasi & Ya & Tidak & Ya & Ya & $\begin{array}{l}\text { Kompetitif } \\
\text { Sementara }\end{array}$ \\
\hline
\end{tabular}

Sumber: data diolah (2016)

Sedangkan kemampuan seperti keuangan, sumber daya manusia, kontrak dan hubungan, serta lokasi geografis hanya memiliki kemampuan paritas kompetitif yang artinya kekuatan dari kemampuan ini untuk bersaing dengan koperasi atau usaha sejenis adalah sama dan hanya dapat memberikan pendapatan dalam kategori normal atau rata-rata. Untuk dapat meningkatkan pendapatan dan bersaing secara sehat dengan dengan usaha sejenis maka Kopkar BSIN 
sebaiknya meningkatkan kemampuan kompetitif setiap sumber daya yang dimiliki agar mencapai kekuatan kompetitif yang berkelanjutan (sustainable competitive advantage)

\section{Analisis Strategi Pemasaran}

Sebagai suatu entitas Koperasi Karyawan Syariah PT. Bridgestone Tire Indonesia (Kopkar BSIN) dan sebagai sebuah organisasi yang dibangun atas dasar kekeluargaan dan kebersamaan untuk mensejahterakan anggotanya, Kopkar BSIN harus merencanakan setiap langkah untuk dapat berkembangan dan bersaing serta mempertahankan usaha yang sudah dibangun selama ini. Agar usaha dapat terus berjalan maka Kopkar BSIN perlu merencanakan, mengembangkan serta mengimplementasikan dan mengevaluasi strategi pemasaran yang akan dilaksanakan. Adapun setiap perencanaan dilakukan bersamaan dengan rapat anggota tahunan dengan sistem budgeting atau anggaran. Pencapaian setiap unit bisnis dilaporkan dan dievaluasi pada rapat anggota tahunan ditahun berikutnya kemudian kembali ditetapkan anggaran pencapaian tahun berikutnya, demikianlah selanjutnya proses penetapan pencapain dan evaluasi dilaksanakan.

Untuk setiap bisnis unit yang dimiliki, kopkar BSIN menggunakan berbagai kebijakan yang berbeda tergantung dari sisi konsumen potensial yang dihadapi. Secara lebih jelas maka berikut pembahasan secara menyeluruh terhadap strategi pemasaran yang dilakukan oleh Kopkar BSIN.

\section{a. Strategi Produk}

Berdasarkan hasil observasi dan wawancara yang dilakukan oleh tim peneliti maka strategi produk yang dilakukan adalah strategi diferensiasi, dimana setiap bisnis unit memiliki perbedaan produk yang secara nyata dan signifikan berbeda satu sama lain. Sebagai contoh unit bisnis toko menawarkan produk berupa barang baik manufacturing maupun hasil industri rumah tangga, baik berupa makanan dan beras maupun non-makanan dan beras seperti pakaian dan asesoris, pembiayaan syariah yang ditawarkan oleh unit usaha simpan pinjam dan pembiayaan syariah, jasa peneydiaan kendaraan oleh unit usaha armada serta catering dan air minum dalam kemasan oleh unit usaha catering dan kantin.

\section{b. Strategi Harga}

Untuk strategi harga, secara jelas maka kopkar BSIN menggunakan metode penentukan harga berdasarkan mark up pricing serta value perception dimana pada saat mengimplementasikannya maka kopkar BSIN menentukan besaran keuntungan yang telah disepakati bersama dalam rapat anggota tahunan. Penerapan strategi harga ini berbeda untuk setiap unit bisnis. Tabel 12 menunjukkan bagaimana penerapannya pada setiap unit bisnis.

Tabel 2. Strategi Harga Kopkar BSIN

\begin{tabular}{ll}
\hline \multicolumn{1}{c}{ Unit Bisnis } & \multicolumn{1}{c}{ Strategi Harga } \\
\hline Toko & Mark up pricing 5\% dari harga pokok \\
Simpan Pinjam dan & Profit Sharing 12\% untuk pembiayaan non pinjaman \\
Pembiayaan Syariah & dan free untuk pinjaman \\
Armada & Cost based Pricing dan Value Perception Pricing \\
$\begin{array}{l}\text { Catering dan Air Minum } \\
\text { dalam Kemasan }\end{array}$ & Cost based Pricing dan Value Perception Pricing \\
\hline
\end{tabular}

Sumber: data dioleh (2016)

c. Strategi Saluran Pemsaran \& Distribusi

Dilihat dari lokasi dan sistem operasional procedural maka strategi saluran pemasaran dan distribusi produk kopkar BSIN masih mengunakan strategi saluran distribusi tanpa perantara dan tradisional yakni dengan menggunakan sistem offline atau menyediakan tempat seperti lokasi toko dan kantin. d. Strategi Komunikasi Pemasaran (promosi) Untuk strategi promosi, kopkar BSIN menggunakan pamphlet, surat elektronik, dan jaringan baik personal, asosiasi maupun ikatan organisasi. Dan selama ini juga masih mengandalkan words of mouth marketing untuk memasarkan produknya. 


\section{Matrix Pemasaran}

Untuk dapat mengevaluasi apakah strategi pemasaran yang dilakukan sudah tepat dan efisien maka tim penulis menggunaka 3 jenis matrix yakni matrik profitabilitas, matrik proses internal dan matrik inovasi. a. Matrix Profitabilitas

Berdasarkan hasil pengolahan data yang tercantum pada tabel 14 dapat dilihat bahwa perputaran persediaan selama 1 tahun hanya terjadi rata-rata 1 kali dalam 1 tahun baik pada periode 2013, 2014 dan 2015.

Tabel 3. Ringkasan Hasil Matrix Profitabilitas

\begin{tabular}{lccc}
\hline Matrix Profitabilitas & $\mathbf{2 0 1 3}$ & $\mathbf{2 0 1 4}$ & $\mathbf{2 0 1 5}$ \\
\hline Inventory Turn Over & $1,013 \mathrm{kali}$ & $1,014 \mathrm{kali}$ & $1,02 \mathrm{kali}$ \\
Sales per Square & $32,871,058.10$ & $33,641,319.18$ & $29,032,906.47$ \\
Meter & $4,74 \%$ & $4,085 \%$ & $4,28 \%$ \\
Return on sales & $1,097 \%$ & $0,918 \%$ & $0,92 \%$ \\
Return on investment & - & - & $73,52 \%$ \\
Return on Marketing & - & & \\
investment & & &
\end{tabular}

Sumber: data diolah (2016)

Hal ini juga menunjukkan bahwa perputaran persediaan pada kopkar BSIN belum berjalan optimal, karena perputaran persediaan yang baik dan optimal adalah lebih dari 2 kali dalam setahun, sehingga dapat membuat suatu organisasi mendapatkan kemampuan menghasilkan laba lebih tinggi.

Untuk hasil penjualan per meter persegi di dalam lingkungan toko dan kantin kopkar dapat dilihat bahwa setiap meter persegi menghasilkan antara Rp. 29 jutaan sampai dengan Rp. 33 jutaan. Hal ini menunjukkan bahwa setiap meter menghasilkan setidaknya $0,15 \%$ dari pendapatan yang diterima kopkar BSIN.

Berikutnya adalah tingkat pengembalian penjualan atau return on sales (ros), ROS menunjukkan perbandingan antara laba bersih dan pendapatan penjualan yang menjelaskan besarnya laba yang diperoleh dari hasil penjualan. Hasil perhitungan menunjukkan bahwa laba rata-rata pada 3 tahun berturut-turut sebesar $4,37 \%$ dari penjualan yang dicapai pada ketiga tahun tersebut. Sedangkan untuk rata-rata return on investment selama 3 tahun sebesar
0,978 \%. Angka ini menunjukkan bahwa pemanfaatan total aset yang dimiliki oleh Kopkar BSIN belum dimanfaatkan secara optimal, karena nilai rata-rata yang diperoleh kurang dari $10 \%$ bahkan tidak mencapai $1 \%$

Untuk return on marketing investment, dapat dilihat bahwa hanya pada tahun 2015 Kopkar BSIN menggunakan biaya pemasaran untuk proses menjalankan kegiatan operasionalnya. Sehingga hanya pada tahun 2015 ROMI Kopkar BSIN dapat diukur dan besarnya mencapai 73,52\%. Angka ini menunjukkan bahwa penjualan yang didapat merupakan $73,52 \%$ dari biaya pemasaran yang telah dikeluarkan oleh koperasi

\section{b. Matrix Proses Internal}

Sebagai bagian dari sebuah sistem dan strategi yang sudah direncanakan maka proses internal menjadi salah satu acuan dalam mengukur kinerja pemasaran dari sisi prosedural. Matrik proses internal akan mengevaluasi apakah proses internal yang dilakukan oleh Kopkar BSIN sudah termasuk kategori dewasa atau belum tabel menunjukkan bagaimana hasil pengukuran matrik proses internal. 
Tabel 4. Ringkasan Hasil Pengukuran Matrik Proses Internal Kopkar BSIN

\begin{tabular}{llllll}
\hline \multicolumn{1}{c}{ Indikator } & \multicolumn{1}{c}{ Sub-Indikator } & P1 & P2 & P3 & P4 \\
\hline Desain & Tujuan & & & & \\
& Isi & & & & \\
& Dokumentasi & & & & \\
Pelaku / Orang yang melakukan & Pengetahuan & & & & \\
& Keahlian & & & & \\
& Perilaku & & & \\
Kepemilikan & Identitas & & & \\
& Aktivitas & & & \\
Infrastruktur & Kewenangan & & & \\
\multirow{4}{*}{ Alat Ukur } & Sistem Informasi & & & \\
& Sistem SDM & & & \\
& Pengertian & & & & \\
& Kegunaan & & & \\
\hline
\end{tabular}

Sumber: data diolah (2016).

Hasil penelitian menunjukkan bahwa proses internal dalam kopkar BSIN sudah sekitar $80 \%$ dijalankan. Hal ini dapat dilihat dari warna hijau disetiap proses pada setiap indikator dan subindikator. Walaupun ada beberapa narasumber yang memberikan pernyataan ragu-ragu dan tidak pada proses dengan indikator tertentu. Namun secara keseluruhan sudah dijalankan secara baik (warna hijau).

\section{c. Matrix Inovasi}

Matrix ini mengevaluasi perkembangan dan inovasi yang telah dilakukan oleh kopkar BSIN berdasarkan kerangka kerja 3 (Tiga) Cakrawalah Pertumbuhan (Three Horizon of Growth).

Kopkar BSIN mengawali usaha dengan menjadi kopkar yang berfokus pada usaha simpan pinjam dna toko dengan tujuan mempermudah karyawan untuk dapat memenuhi kebutuhan pokok dan dana urgen. Hal ini karena pada saat itu terjadi keterbatasan dana keuangan yang dimiliki oleh kopkar BSIN untuk membuka usaha lain. Seiring pertumbuhan pendapatan dan perkembangan jumlah anggota serta kenaikan simpanan pokok anggota, maka dengan adanya perkembangan bisnis dan peluang maka didirikanlah unit usaha armada guna melayani kebutuhan perusahaan induk dalam hal pendistribusian produk yang dihasilkan kepada showroom dan dealer. Perkembangan bisnis yang bagus didukung kerjasama dengan kantor induk yakni PT. Bridgestone Tire Indonesia maka kopkar BSIN bekerja sama dengan perusahaan catering untuk memberikan layanan makan karyawan yang berada di pabrik. Kerjasama yang baik menciptakan dan membuat unit usaha catering berjalan baik dan lancar sehingga untuk menunjang usaha catering dibuatlah usaha air minum dalam kemasan. Hingga saat ini kopkar BSIN memiliki 4 unit usaha yaitu: toko, simpan pinjam dan pembiayaan syariah, armada dan catering dan air minum dalam kemasan.

Setelah beberapa tahun berjalan dengan keempat unit bisnisnya, maka pada tahun 2014 diputuskan secara bersama dalam rapat anggota tahunan bahwa kopkar BSIN yang pada awalnya menganut sistem konvensional yang menerapkan bunga untuk pinjaman dan pembiayaan beralih menjadi kopkar yang berpedoman pada syariah Islam yang menganut sistem bagi hasil (profit sharing). Pada tahun 2015 dideklarasikan bahwa Koperasi Karyawan BSIN menjadi Koperasi Karyawan Syariah dan proses penyesuaian pun mulai dijalani. Dilihat dari ulasan sekilas mengenai perkembangan bisnis unit yang ada dalam portofolio Kopkar BSIN maka transformasi dan inovasi yang terjadi dalam kopkar BSIN masih dalam horizon 1 yakni fokus utama adalah bisnis atau usaha yang sedang dijalani saat ini. dengan kata lain, segala sesuatu saat ini adalah tentang inti bisnis yang sedang perusahaan atau organisasi jalankan. Apakah keuntungan saat ini sudah mencapai puncaknya, tidak berubah atau telah menurun? Fase ini 
membutuhkan kemampuan pemimpin untuk dapat mempertimbangkan dan juga mengumpulkan nilai atau keuntunga sisa dari semua jenis atau portofolio usaha yang dimiliki. Pada horizon ini, sangat penting bagi perusahaan atau organisasi untuk melihat dan mempertimbanggkan potensi kelemahan dari inti bisnis yang saat ini dijalani untuk menghadapai tantangan dimasa yang akan datang. Namun juga tidak dapat dipungkiri bahwa dengan transformasi konsep strategi bisnis kopkar BSIN juga sedang menuju horizon yang ke

\section{SIMPULAN DAN SARAN}

Berdasarkan hasil penelitian yang dilakukan oleh tim pengusul maka didapat hasil sebagai berikut:

1. Hasil analisisi VRIO menunjukkan bahwa sebagian besar dari sumber daya yang dimiliki oleh kopkar BSIN merupakan faktor yang dapat membuat kemampuan kompetitif sementara dan memberikan hasil diatas ratarata dan beberapa diantaranya memiliki kekuatan yang sama (competitive parity) dengan pesaing yang memberikan dampak ekonomi sama dengan yang lainnya

2. Hasil analisis matrix profitabilitas menunjukkan bahwa kemampuan mendapatkan profit atau keuntungan dari sisi pemasaran dinilai masih belum optimal hal ini karena hasil dari masing-masing item yang dinilai seperti inventory turn over (ITO), Return on Sales (ROS), Return on Investment (ROI) dan Return on Marketing Investment (ROMI) (tahun 2013-2014) masih menunjukan angka yang kecil kisaran $0-5 \%$, bahkan untuk perputaran persediaan hanya 1 kali dalam 1 tahun. Sedangkan untuk ROMI baru berjalan pada tahun 2015 yang hasilnya cukup besar yaitu $73,52 \%$

3. Untuk hasil matrix proses internal, proses internal kopkar BSIN menunjukkan bahwa setiap indikator seperti desain proses, pelaku, kepemililikan dan infrastruktur masuk dalam katagori baik. Sedangkan untuk alat ukur atau pengukur kinerja proses, sepertinya para pengurus, pengelola dan karyawan masih belum menemukan metode tepat untuk mengukur setiap proses dan hasil dari proses yang dilakukan sehingga cenderung merasa ragu-ragu terhadap proses internal.

4. Hasil matrix inovasi menunjukkan bahwa saat ini kopkar BSIN masih dalam horizon 1 dan sedang bertransformasi menuju horizon 2 untuk menemukan momentum perkembangan bisnisnya.

5. Secara keseluruhan, implementasi strategi pemasaran pada KopKar BSIN dapat dinyatakan baik hanya saja proses dari perencanaan dan implementasi masih harus diperhatikan dengan seksama. Hal ini dikarenakan posisi persaingan kopkar BSIN masih termasuk dalam kategori competitive parity yang dapat berakibat fatal apabila tidak ada konsistensi pengembangan kemampuan dan strategi dalam pengelolaan unit bisnisnya.

Adapun beberapa saran yang dapat diberikan untuk kopkar BSIN terkait hasil penelitian ini adalah:

1. Sebaiknya proses perencanaan strategi pemasaran dibahas secara rinci per langkah sehingga jelas tujuan dari strategi yang dibuat.

2. Untuk memaksimalkan kemampuan menghasilkan laba maka sebaiknya kopkar mengevaluasi tingkat persediaan dan harga bagi produk di unit usaha toko, serta mempertimbangkan kembali untuk dapat menggunakan elemen dari strategi promosi yang ada sehingga perputaran persediaan menjadi lebih cepat.

3. Perlu adanya metode pengukuran kinerja proses selain dari sisi keuangan sehingga dapat dengan mudah menentukan apakah proses yang selama ini dilakukan sudah sesuai atau belum.

4. Perlu adanya kerjasama dan komitmen berbagai pihak baik pengurus, pengelola, anggota dan karyawan untuk dapat bertransformasi menjadi koperasi karyawan yang terbaik di Indonesia.

5. Pelatihan secara berkala bagi karyawan dan mengembangan diri terutama jenjang pendidikan agar mindset dan cara berpikir karyawan berubah dan dapat menjadi manusia pembelajan.

\section{DAFTAR RUJUKAN}

\section{Barney, Jay. 1991. Firm resources and sustaine competitive advantage. Journal of management. Vol. 16: 7 - 19}


Creven, David W. and Piercy, Nigel F. 2013. Strategic Marketing. Tenth Edition. International Edition. New York. McGraw Hill Education.

Grant, Robert. 2008. Contemporary Stratagic Analysis. Sixth Edition, Victoria, Australia. Black Well Publishing

Hammer, Micheal. 2007. The Process Audit. Harvard Business Review. Vol. 85 No. 4. Mei. Hal: 111-9, 122-3, 142

Kotler, Philip and Kevin Lane Keller. 2016. Marketing Management. $15^{\text {th }} \mathrm{Ed}$. Global Edition. England. Pearson Education Limited.

Kyffin, Steven dan Paul Gardien. 2009. Navigating the Innovation Matrix: An Approach to Design-led Innovation. International Journal of Design. Vol. 3 No. 1. Diakses melalui http://www.ijdesign.org/ojs/index.php/IJD esign/article/view/305/242.\#9

Sugiyono. 2012. Metodologi Penelitian Kombinasi. Bandung: Alfabeta.

Tjiptono, Fandy dan Chandra, Gregorius. 2012. Pemasaran Strategik, Edisi 2. Yogyakarta: ANDI. 